\title{
Processed Z. Mauritiana Lamk in the Formula of High Nutritional Value Cake
}

\author{
Zozio $S^{1,2}$, Servent $A^{2}$, Hiol $A^{3}$, Mbeguie-A-Mbeguie $D^{1,2}$, Cosmidis $L^{2}$, Lucien $\mathrm{JM}^{2}$ and Pallet $D^{2}$ \\ ${ }^{1}$ CIRAD, UMR QUALISUD, F- 97130 Capesterre-Belle-Eau, Guadeloupe, France \\ ${ }^{2}$ CIRAD, UMR QUALISUD, F-34398 Montpellier, France \\ ${ }^{3}$ CIRAD, UMR QUALISUD University of Reunion - ESIROI, Specialty Food, PTU - 97490, France
}

\begin{abstract}
The nutritional value of jujube fruits Ziziphus mauritiana Lamk was processed through an optimized traditional cake procedure. The characteristics of jujube fruit polysaccharides from an accession known as P3 were determined for each of the 5 ripening stages. Therefore, the content of the Alcohol Insoluble Materials, Water Soluble Polysaccharide and Galacturonic Acid was determined at each ripening stage. The degree of methylation (DM) of jujube pectins was less than $50 \%$ therefore was classified as low methoxylated pectin (LM). Using the $3^{\text {rd }}$ and the $5^{\text {th }}$ ripening stage, the impact of the drying and cooking was evaluated on selected nutritional characteristics, including vitamin $\mathrm{C}$, total phenolics content and antioxidant capacity. Remarkably, using the fruits from the $3^{\text {rd }}$ stage, the drying process decreased the vitamin $C$ content $(74.5 \%, p<0.05)$ whereas an increase of $20 \%$ ( $\left.p<0.05\right)$ was observed for the cake. Interestingly, the antioxidant activity was unchanged during the drying process. In contrast, after the cooking process the phenolics content and the antioxidant capacity had both increased, by $64 \%$ and $30 \%$ ( $p<0.05$ ) respectively.
\end{abstract}

Overall, our results indicated that stage 3 fruits would exhibit higher nutritional qualities than stage 5 fruits. We strongly recommend stage 3 fruits of accession P3 for food applications, including jujube cake processing.

Keywords: Jujube process; Cake nutritional; Polyphenols; Vitamin C; Antioxidant

\section{Introduction}

The jujube fruit (Ziziphus mauritiana Lamk.), known as "pommesurette" in Guadeloupe, is underutilized despite its high nutritional value and its biological properties, underlined by various triterpenoid acids, flavonoids, phenolic acids, cytokinins and tannins [1]. Furthermore, previous studies have revealed a high antioxidant capacity [2-4]. Nevertheless, a huge range of food products have been established, including compotes, alcoholic beverages, flours, chutneys, pickles and some cakes in India [5]. However, rapid perishability is a problem for postharvest management and further processing [6]. Depending on their ripening stages, the fruit skin color shifts from green to yellow, eventually reaching a reddish-brown color. Then, the harvested fruits can be classified into five ripening stages as showed in the previous work. A recent study on polysaccharides from Ziziphus mauritiana indicates that they have rheological properties [7]. High DM pectin (high methoxylated (HM), DM >50\%) can form a gel in acidic conditions in the presence of high sugar concentration. Conversely, gelation of low methoxyl pectin (LM, DM <50\%) occurs at higher $\mathrm{pH}$ in the presence of divalent ions, such as calcium, which acts as a bridge between pairs of carboxyl groups of different pectin chains. The main industrial sources for pectin extraction are apple pomace and citrus peels, which provide HM pectin. LM pectin can be obtained after chemical de-esterification of HM pectins. However, this process often induces pectin depolymerization, thus reducing the gelforming ability of pectin [8]. Furthermore, polysaccharides extracted from plants and fungi have been identified for their anti-oxidative and hepatoprotective effect [9] and also for their immunobiological, anti-viral, anti-tumor and other biological activities [10] Hence, the composition of polysaccharides from the species Ziziphus jujuba growing in China has been elucidated [11,12]. In Africa, a traditional cake known as "yaabande" is made with harvested mature fruits and dry grains fallen from jujube trees onto the ground [13]. However, the ripening stage has not been clearly defined. Thus, in order to combine processing and the biochemistry characteristics of jujube during the ripening, we evaluated the nutritional value of an optimized cake. Hence, we first characterized the polysaccharides during ripening in order to assess the rheological properties. Subsequently, we chose 2 ripening stages based on nutritional properties and the traditional processing method, to evaluate the impact of ripening on the quality of jujube cake, previously optimized. In addition, the impact of the process (drying and steam cooking) on the content of vitamin C, total phenolics and antioxidant capacity of the jujube cake was investigated. The optimized process was set as follows: drying parameters $\left(45^{\circ} \mathrm{C} / 30\right.$ $\mathrm{h})$, size grading of jujube flour $(465 \mu \mathrm{m})$ and cooking parameters $(10$ mins $/ 100^{\circ} \mathrm{C}$ in a steam oven). The present work was carried out to improve the seasonal feature of jujube for a diet application as flour and as cake. Our results strongly suggested that jujube fruits taken at stage 3 may provide high nutritional value and elevated antioxidant activity, in both the flour and the cake.

\section{Material and Methods}

\section{Materials}

Jujube fruit from the cultivar P3 were harvested in January 2012 on a local farm based in the south of the island under wild conditions, following the five ripening stage as described in the previous work. The fruits were washed with $1 \%$ chlorinated water and rinsed with

*Corresonding author: Abel Hiol, 3CIRAD, UMR QUALISUD University of Reunion - ESIROI, Specialty Food, PTU - 97490, France, Tel: +33 2622116 26; E-mail: abel.hiol@univ-reunion.fr

Received February 04, 2015; Accepted March 27, 2015; Published April 03, 2015

Citation: Zozio S, Servent A, Hiol A, Mbeguie-A-Mbeguie D, Cosmidis L, et al. (2015) Processed Z. Mauritiana Lamk in the Formula of High Nutritional Value Cake. J Food Process Technol 6: 444. doi:10.4172/2157-7110.1000444

Copyright: @ 2015 Zozio S, et al. This is an open-access article distributed unde the terms of the Creative Commons Attribution License, which permits unrestricted use, distribution, and reproduction in any medium, provided the original author and source are credited. 
water. Then the fruits were stored for four days in air at $20^{\circ} \mathrm{C}$ in order to homogenize their internal temperature and to reveal any putative injured fruits that might not have been observed during harvesting. Ethylene production was measured in order to check the physiological stage of the fruit samples. The fruit from ripening stage 3 and 5 were kept, the fruits from stage 2 were matured until stage 3 , and the stage 4 fruits until stage 5 . Then 2 jujube lots were frozen before processing: stage 3 fruits were designated "Fruits 3" and stage 5 fruits, as "Fruits 5".

\section{Jujube cake processing}

The processing of jujube cake comprised three individual steps: drying, grinding and cooking (Figure 1). The drying was optimized with a horizontal air outlet dryer (UTA, Marmande, France) with three parameters: temperature, time and fruit configuration (whole/ sliced/grinded). The impact of the flour grading on the consistency of the cake was also evaluated. The cooking parameters (time, quantity of flour and type of mold) were optimized with an Emeraude 3 steam oven (Thirode, Mitri-mory, France).

Sensory evaluation of the cake samples was carried out by 5 semitrained panelists from CIRAD Montpellier.

\section{Physico-chemical parameters analysis}

Determination of jujube flour grading: The particle size was determined by the Mastersizer 3000 laser diffraction particle size analyzer (Malven Instruments, Malvern, Worcestershire, UK) at a grinding speed of $1500 \mathrm{rpm}$. The mean of 6 measurements was used to estimate the particle size of 3 grading flours.

Determination of jujube cake firmness: Jujube cake firmness was measured by a texture analyzer (Stable Micro Systems TAXT PLUS). Preliminary experiments were conducted to optimize the process conditions with a ball probe adjusted for $70 \%$ deformation of the cake, with a speed of $0.7 \mathrm{~mm} / \mathrm{s}$. The force recorded in Newtons $(\mathrm{N})$ was given

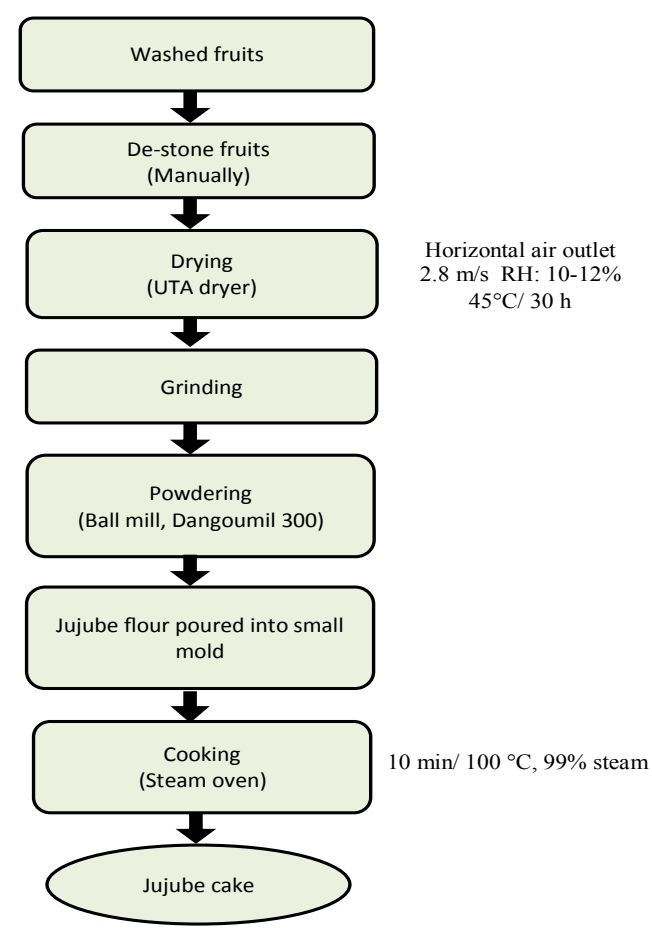

Figure 1: Diagram of jujube cake processing. as firmness. This measurement corresponds to the force needed to give a deformation of $70 \%$. The more flexible the cake, the less it was deformed.

\section{Biochemical analysis}

The chemical analysis was performed on the fruits, flours and cakes from the ripening stage 3 and 5 in order to evaluate the effect of processing on nutritional qualities of jujube fruit.

Total soluble solids and titratable acid content: The fruits, flours or cakes were homogenized with a blender and centrifuged for $1 \mathrm{~h}$ at $10,000 \times \mathrm{g}$ and $4^{\circ} \mathrm{C}$. The supernatant was collected for analysis of total soluble solids, $\mathrm{pH}$ and titratable acidity. The level of total soluble solids was determined using a digital Refracto 30PX/GS refractometer from Mettler Toledo, (Grosseron, Saint-Herblain, France). pH and titratable acidity expressed as citric acid were determined by titration with $0.1 \mathrm{~N}$ $\mathrm{NaOH}$ using a TitroLine easy apparatus from SCHOTT Instrument (Bioblock, Illkirch, France).

Determination of ascorbic acid content: Five hundred milligram of fruits, flours or cakes were stirred in $10 \mathrm{ml}$ of methaphosphoric acid $4 \%$ for 10 mins, and then centrifuged for 10 mins at $10,000 \mathrm{rpm}$. The remaining supernatant was then filtered through a $0.45 \mu \mathrm{m}$ filter (Millipore) and then analyzed by HPLC using a 1200 series HPLC Agilent System.

Total phenolics (TP) content: Total phenolics content was evaluated spectrometrically method using the Folin-Ciocalteu reagent as per the method of [14] modified for a TECAN Infinite 200 96-well plate reader. Catechin was used as a standard to quantifying the TP content in fruits, flours and cakes. The results were expressed in $\mathrm{mg}$ catechin equivalent $(\mathrm{CE}) / 100 \mathrm{~g}$.

Antioxidant capacity determination: The FRAP assay was carried out on a TECAN Infinite 200 96-well plate reader (TECAN Austria GMBH) as per [15] Trolox was used as a standard to quantify the TP content in fruits, flours and cakes. The results were expressed in mmol Trolox equivalent (TE)/100 g.

\section{Polysaccharide analysis}

Extraction method: Polysaccharide extraction from jujube fruits was carried out as per the modified method based on [16] Lyophilized jujube fruits were refluxed with $96 \%$ ethanol at $70^{\circ} \mathrm{C}$ for $1 \mathrm{~h}$, and this step was repeated 3 times. Subsequently, the dried ethanol-extracted residue was extracted with distilled water at $80^{\circ} \mathrm{C}$ for $3 \mathrm{~h}$. After one night of decantation at $4^{\circ} \mathrm{C}$, the aqueous part was recovered by centrifugation $\left(4^{\circ} \mathrm{C} / 20 \mathrm{mins} / 10000 \mathrm{~g}\right)$ and concentrated. The polysaccharide was isolated by mixing 3 volumes of cold $96 \%$ ethanol. The precipitate was recovered by centrifugation $\left(4^{\circ} \mathrm{C} / 20 \mathrm{mins} / 10000 \mathrm{~g}\right)$, and finally lyophilized. Brown water-soluble polysaccharide (WSP) was obtained.

Galacturonic acid content determination: Galacturonic acid content was determinate as previously [17] reported with slightly modifications. Five milligrams of polysaccharide from each ripening stage was poured into a screw-capped tube, then $1 \mathrm{ml}$ of sulfuric acid was added for hydrolysis for $3 \mathrm{~h}$ at $20^{\circ} \mathrm{C}$. After dilution and filtration thought gauze, $500 \mu \mathrm{l}$ was mixed thoroughly with $2.5 \mathrm{ml}$ of $0.125 \mathrm{M}$ sodium tetraborate in sulfuric acid and immediately cooled in an icebath. Then, all the tubes were heated to $80^{\circ} \mathrm{C}$ for $6 \mathrm{mins}$, cooled, added to $50 \mu \mathrm{l}$ of $0.15 \% \mathrm{~m}$-hydroxybiphenyl in $0.125 \mathrm{M}$ sodium hydroxide, and vortex agitated; the absorbance at $520 \mathrm{~nm}$ was then measured every 2 mins for 20 mins. The maximum absorbance was used to determine the galacturonic content based on the standard curve, which was 
prepared using 7 concentrations $(5,10,20,40,60,80$ and $100 \mu \mathrm{g} / \mathrm{mL})$ of galacturonic acid standard. The straight-line equation obtained for the standard curve was $\mathrm{y}=0.0112 \mathrm{x}-0.0147$ with an $\mathrm{R}^{2}$ value of 0.9902 .

Degree of Methylation (DM) estimation: The degree of methylation of jujube pectins from the five ripening stages was determined using a modified method based on. Huisman et al. [18]. The pectin DM is expressed as the percentage of the total number of galacturonic acid residues esterified with a methoxyl group. SPME/ CG by standard addition was used to quantify methanol released from pectic material by saponification. Five milligrams of WSP was weighed into a headspace vial (in quadruplicate) and $1 \mathrm{ml}$ of $2 \mathrm{~N} \mathrm{NaOH}$ was added. $1 \mathrm{ml}$ of deionized water was added to the samples (duplicate), and $1 \mathrm{ml}$ of methanol to the spikes (duplicate). The vials were sealed and kept at $4^{\circ} \mathrm{C}$ for $1 \mathrm{~h}$, and then 20 mins at room temperature, and subsequently analyzed. The vials were heated to $85^{\circ} \mathrm{C}$ for $15 \mathrm{mins}$ in a the head-space sampler, then an SPME fiber PDMS/DVB $(85 \mu \mathrm{m}$ stableflex, Chromoptique, Courtaboeuf, France) was exposed to the headspace vials while the extract was continuously stirred for 15 mins. Methanol was desorbed by inserting the SPME fiber into a GC injector (injector temperature $250^{\circ} \mathrm{C}$ ) for $30 \mathrm{~s}$ in splitless mode connected with DB-WAX column ( $30 \mathrm{~m}, 0.25 \mathrm{~mm}$ ID, $0.25 \mu \mathrm{m}$ film thicknesses) for 60 mins. The integration was achieved using MSD ChemStation software. The degree of methylation was estimated using Equation 1 below:

$$
D M=\frac{{ }^{m} \text { Methanol }}{{ }^{M M} \text { Methanol }} X \frac{{ }^{M M} \text { Uronic acid }}{{ }^{M} \text { Uronic acid }} \times 100
$$

Where: $\mathrm{m}=$ mass ( $\mathrm{g}$ ), MM Methanol=32 $\mathrm{g} / \mathrm{mol}$, MM Uronic acid $=176 \mathrm{~g} / \mathrm{mol}$

\section{Statistical analysis}

The data were subjected to Analysis of Variance (ANOVA) using STATISTICA software (Statsoft, version 7).Duncan's Multiple Range test $(\mathrm{p}<0.05)$ was applied to calculate the significant difference between the different ripening stages and treatments. Unless otherwise stated analyses were performed on three or more biological replicates and the results were expressed as the mean \pm standard deviation.

\section{Results}

\section{The jujube cake processing}

Impact of temperature and fruit configuration on quality of drying: The temperature and fruit configuration have a high impact on quality of drying, as shown in Table 1. Whole and scalped fruits were dried only on the skin, and were finally burned, whereas the pulp was candied. However fruits sliced before drying exhibited acceptable drying. Conversely, the ground fruits formed a kind of mesh during drying, and became very hard.

\begin{tabular}{|c|c|c|c|c|}
\hline $\begin{array}{c}\text { Step of } \\
\text { experiment }\end{array}$ & $\begin{array}{c}\text { Configuration } \\
\text { of fruits }\end{array}$ & $\begin{array}{c}\text { Temperature } \\
\text { applied }{ }^{\circ} \mathbf{C}\end{array}$ & $\begin{array}{c}\text { Quality of } \\
\text { drying }\end{array}$ & Observations \\
\hline 1 & Whole & 60 & + & $\begin{array}{c}\text { Burnt skin, Pulp not } \\
\text { dried }\end{array}$ \\
\hline 2 & Whole & 45 & + & Pulp not dried \\
\hline 3 & Scalped & 50 & + & Skin burned \\
\hline 4 & Sliced & 35 & + & Correctly dried \\
\hline 5 & Ground & 35 & ++ & Pulp not dried \\
\hline 6 & Sliced & 45 & +++ & Formation of a hard \\
mesh
\end{tabular}

Table 1: Impact of fruit configuration and temperature on quality of drying. The quality of drying was defined by the number of $(+)$ symbols: slightly dry $(+)$, moderately dry $(++)$ and correctly dry $(+++)$.

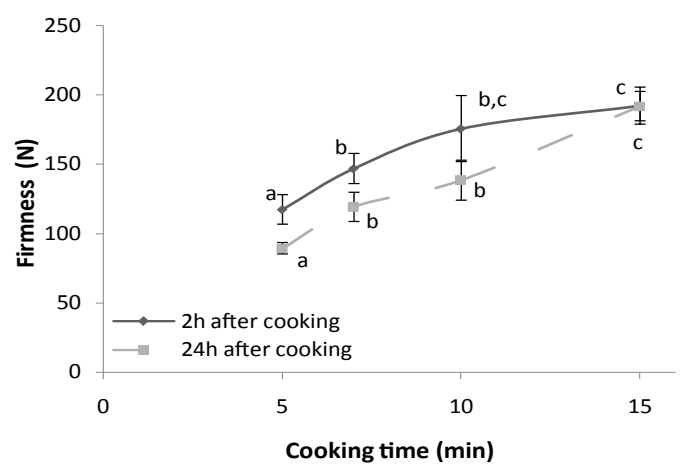

Figure 2: Evolution of firmness of jujube cakes as a function of cooking time $(5,7,10$ and $15 \mathrm{mins})$ monitored at $2 \mathrm{~h}$ and $24 \mathrm{~h}$ after the end of cooking Mean values with different small letters in the same curve are statistically significant $(p<0.05)$

\begin{tabular}{|c|c|c|}
\hline Grading nomenclature & Grading $(\boldsymbol{\mu m})$ & Consistency of cake \\
\hline Fine & $75^{\mathrm{a}}(1.70)$ & Pasty and sticky \\
\hline Intermediate & $465^{\mathrm{b}}(24.70)$ & Soft and melting \\
\hline Coarse & $812^{\mathrm{c}}(61.78)$ & Grainy \\
\hline
\end{tabular}

Values are means with standard deviations of triplicate determinations. Mean values of grading with different small letters are statistically significant $(p<0.05)$

Table 2: Impact of the jujube flour grading on cake consistency.

Impact of cooking time on consistency of cakes: The cooking time $(5,7,10$ and 15 mins) was monitored. The consistency changed and became more compact as time increased, exhibiting loss of the flavor and aroma characteristics. Firmness was determined $2 \mathrm{~h}$ and 24 $\mathrm{h}$ after baking, to evaluate the possible modification of the consistency due to water absorption.

The cake firmness increased with cooking time (5 to 15 mins, $\mathrm{p}<0.05)$, both $2 \mathrm{~h}$ and $24 \mathrm{~h}$ after the end of cooking. However an insignificant increase ( $p>0.05)$ was observed between 7 mins to 10 mins of cooking, regardless of the measurement $(2 \mathrm{~h}$ or $24 \mathrm{~h}$ ). In addition, no significant difference $(\mathrm{p}>0.05)$ between $2 \mathrm{~h}$ and $24 \mathrm{~h}$ was observed after 7 mins of cooking (Figure 2).

Optimization of flour grading on cake consistency: The flour grading was shown to have an impact on the cake consistency. The fine and coarse grading gave a sticky consistency irrespective of the cooking time. However, the intermediate grading $(465 \mu \mathrm{m})$ was chosen for baking jujube cakes, because of the soft and melting texture (Table 2).

Nutritional quality improvement of the reengineered jujube cake

Nutritional quality of Fruit 3 compared to Fruit 5: In order to evaluate the impact of ripening stage on the nutritional quality of jujube cake, Fruits 3 and Fruits 5 were used in processing to make jujube cake. Chemical analyses were carried on fruits, flours and cakes. Fruits 3 exhibited high ascorbic acid content $(267.78 \mathrm{mg} / 100 \mathrm{~g} \mathrm{DW})$, with a large decrease in Fruits 5 (98\%) (Table 3). This last ripening stage (Fruit 5 ) also showed a lower total phenolics content (61\%) and antioxidant capacity (87\%) than Fruit 3 (Figures 3 and 4). Previous works have highlighted the decrease in nutritional quality during ripening.

Combined effects of ripening stages and processing on nutritional quality of jujube cake: Flour from the ripening stage 3 was designated "Flour3", and flour from stage 5 "Flour 5". Likewise, cakes 
Citation: Zozio S, Servent A, Hiol A, Mbeguie-A-Mbeguie D, Cosmidis L, et al. (2015) Processed Z. Mauritiana Lamk in the Formula of High Nutritional Value Cake. J Food Process Technol 6: 444. doi:10.4172/2157-7110.1000444

Page 4 of 6

\begin{tabular}{|c|c|c|c|c|c|c|}
\hline \multirow[t]{2}{*}{ Characteristics } & \multicolumn{2}{|c|}{ Fruits } & \multicolumn{2}{|c|}{ Flours } & \multicolumn{2}{|c|}{ Cakes } \\
\hline & Stage 3 & Stage 5 & Stage 3 & Stage 5 & Stage 3 & Stage 5 \\
\hline Pulp (\%) & $\begin{array}{l}88.89 \\
(0.28)\end{array}$ & $\begin{array}{l}84.25 \\
(1.48)\end{array}$ & - & - & - & - \\
\hline $\mathrm{pH}$ & $\begin{array}{c}3.33 \\
(0.05)\end{array}$ & $\begin{array}{c}3.52 \\
(0.03)\end{array}$ & $\begin{array}{l}3.43 \\
(0.01)\end{array}$ & $\begin{array}{c}3.43 \\
(0.02)\end{array}$ & $\begin{array}{l}3.43 \\
(0.04)\end{array}$ & $\begin{array}{c}3.43 \\
(0.06)\end{array}$ \\
\hline TSS*(\% DW) & $\begin{array}{c}60.2 \\
(3.67)\end{array}$ & $\begin{array}{l}81.27 \\
(0.40)\end{array}$ & $\begin{array}{l}82.63 \\
(1.19)\end{array}$ & $\begin{array}{l}74.47 \\
(1.2)\end{array}$ & $\begin{array}{l}80.12 \\
(2.32)\end{array}$ & $\begin{array}{l}75.21 \\
(1.21)\end{array}$ \\
\hline Titratable acidity $(\%)$ & $\begin{array}{l}1.23 \\
(0.01)\end{array}$ & $\begin{array}{c}1.41 \\
(0.049)\end{array}$ & $\begin{array}{l}7.29 \\
(0.05)\end{array}$ & $\begin{array}{l}7.38 \\
(0.02)\end{array}$ & $\begin{array}{c}6.54 \\
(0.06)\end{array}$ & $\begin{array}{l}6.66 \\
(0.04)\end{array}$ \\
\hline TSS/Titratable acid & 9.75 & 10.71 & 11.11 & 9.65 & 12.25 & 10.60 \\
\hline Total sugar (\%) & - & - & $\begin{array}{l}24.00 \\
(0.67)\end{array}$ & $\begin{array}{l}24.42 \\
(0.72)\end{array}$ & $\begin{array}{l}23.65 \\
(0.86)\end{array}$ & $\begin{array}{l}23.84 \\
(0.97)\end{array}$ \\
\hline Dry matter (\%) & $\begin{array}{l}19.92 \\
(0.09)\end{array}$ & $\begin{array}{l}18.58 \\
(0.38)\end{array}$ & $\begin{array}{l}98.05 \\
(0.02)\end{array}$ & $\begin{array}{l}95.63 \\
(0.05)\end{array}$ & $\begin{array}{l}96.77 \\
(0.75)\end{array}$ & $\begin{array}{l}93.89 \\
(0.37)\end{array}$ \\
\hline $\begin{array}{l}\text { Ascorbic acid } \\
(\mathrm{mg} / 100 \mathrm{~g} D W)\end{array}$ & $\begin{array}{c}267.78 \\
(7.54)\end{array}$ & $\begin{array}{c}5.64 \\
(0.32)\end{array}$ & $\begin{array}{l}68.28 \\
(4.15)\end{array}$ & $\begin{array}{c}1.37 \\
(0.04)\end{array}$ & $\begin{array}{l}82.21 \\
(6.23)\end{array}$ & $\begin{array}{l}6.60 \\
(0.09)\end{array}$ \\
\hline
\end{tabular}

*TSS: Total Soluble Solid

Values are means with standard deviations of triplicate determinations

Table 3: Physico-chemical characteristics of jujube fruits, flours after drying and cakes after cooking from ripening stages 3 and 5 .

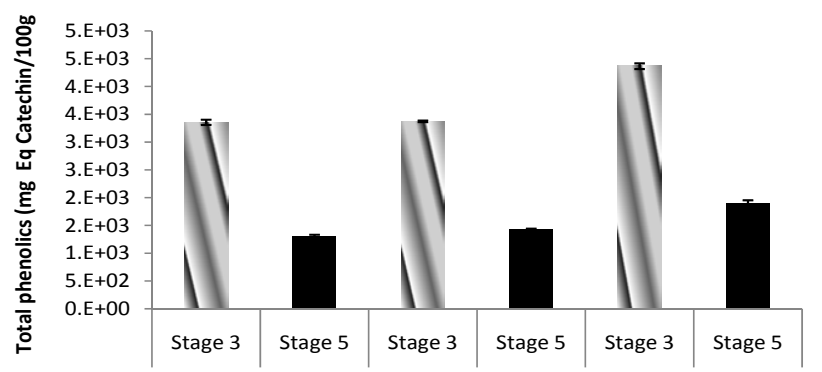

Figure 3: Effect of the drying and cooking on total phenolics of jujube fruits from ripening stages 3 and 5 . The results are expressed in mg equivalent catechin $100 \mathrm{~g} \mathrm{DW}$.

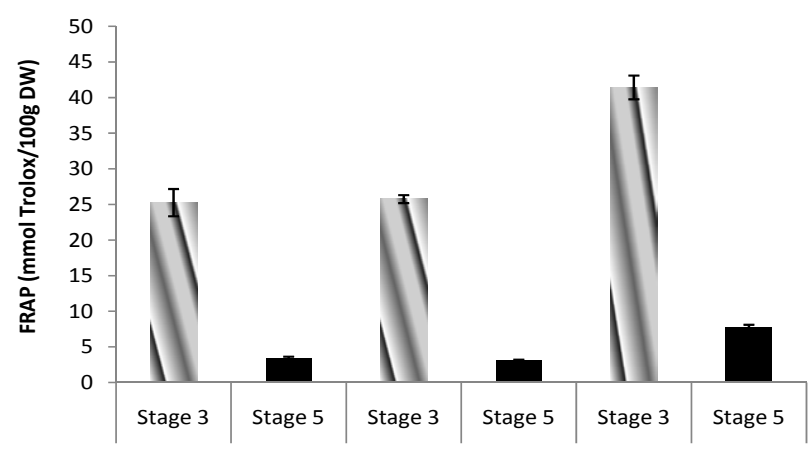

Figure 4: Effect of drying and cooking on the antioxidant capacity of jujube fruits from ripening stages 3 and stages 5 . The antioxidant capacity was measured by FRAP assay and expressed in mmolTrolox / $100 \mathrm{~g} \mathrm{DW}$ of fruits, flours or cakes

from Flour 3 were designed "Cakes 3" and cakes from flour 5, "Cakes 5".

Unexpectedly, the drying process did not negatively affect the total phenolics content or the antioxidant capacity, irrespective of the ripening stage (Figures 3 and 4). Conversely, ascorbic content was reduced dramatically ( $\mathrm{p}<0.05$ ): $74.5 \%$ in Flour 3 and $76 \%$ for Flour 5 (Table 3). A previous study on $Z$.jujuba showed a decrease of vitamin C (65\%), phenolic content (32\%) and antioxidant activity (40\%) during drying at $65^{\circ} \mathrm{C}$ [19]. Surprisingly, the Cakes 3 and Cakes 5 exhibited an increase of total phenolics content $(30 \%, \mathrm{p}<0.05)$, and also for the antioxidant capacities $(60 \%, \mathrm{p}<0.05)$ compared to the corresponding flour (Figures 3 and 4). A similar antioxidant improvement during steam cooking was found in jujube cake. This enhancement may be due to naturally occurring compounds or formation of new compounds, such as Maillard reaction products with antioxidant activity [20]. Furthermore, cooking was found to increase total phenolics in green beans, pepper and broccoli [21]. It was reported that heat treatment increased the level of free flavonols in tomatoes by releasing conjugated quercetin as rutin [22]. A study on phenolic acids of citrus peel showed that the free compounds increased after heat treatment; as opposed to ester, glycoside and ester-bound compounds which declined, as did flavanone glycosides [23]. Phenolic compounds are present in different bound states in plants [24,25] and may be cleaved and rearranged into more soluble forms by thermal processing, which leads to an increase in antioxidant activity [26]. In a previous study, an increase of p-coumaric acid (1.8 to $4.3 \mathrm{mg} / \mathrm{kg} \mathrm{DW}$ ) and ferulic acid (48\%) were found after sun-drying of $Z$. jujuba [27] and after microwave, vacuum and roasting treatment for p-coumaric acid [28]. Likewise, ascorbic acid content showed a significant increase $(\mathrm{p}<0.05)$ from the Flour 3 to Cakes 3 (20\%). Surprisingly, the ascorbic acid content increased 5 fold with Cakes 5 compared to Flour 5 (Table 3).

\section{Characterization of the polysaccharide extract from jujube}

WSPs from jujube fruits were obtained by precipitation with alcohol from the aqueous extract of the alcohol-insoluble material (AIM). The AIM increased slowly from the 1 st to the 4 th ripening stage $(38.47 \%$ to $47.40 \% \mathrm{DW}, \mathrm{p}<0.05$ ), before a decrease at the end of the ripening (5th stage: $39.13 \% \mathrm{DW}, \mathrm{p}<0.05)$. The resulting WSPs exhibited a constantly high value $(\approx 6 \%)$ during ripening. Previous studies by Kannan et al. [29] pointed to very low pectin content in unripe and ripe Z. mauritiana $(0.39 \%$ and $0.18 \%$ respectively). However, an increase was observed during ripening in unripe $(\approx 0.7 \% \mathrm{DW})$ and ripe $(\approx 3 \% \mathrm{DW})$ fruits of the $Z$. jujube Huanghua cultivar, whereas a constant value $(\approx 3 \% \mathrm{DW})$ was obtained for the Zhanhua cultivar [30]. The content of uronic acid extracted from the WSP showed a global increase from the 1st to the 5 th ripening stage $(41 \%, \mathrm{p}<0.05)$. For the $\mathrm{DM}$, a global decrease was observed from the 1 st to 5 th ripening stage $(19 \%, \mathrm{p}<0.05)$ (Table 4$)$.

\section{Discussion}

Jujube cake preparation was optimized in a steam oven using various temperatures and cooking times, different flour grading and 


\begin{tabular}{|c|c|c|c|c|}
\hline $\begin{array}{c}\text { Ripening } \\
\text { stage }\end{array}$ & $\begin{array}{c}\text { AlM } \\
\text { (\%DW) }\end{array}$ & $\begin{array}{c}\text { WSP } \\
\text { (\% DW) }\end{array}$ & $\begin{array}{c}\text { GuAc } \\
\text { (\% WSP DW) }\end{array}$ & DM (\%) \\
\hline 1 & $38.47^{\mathrm{a}}(4.39)$ & $6.06^{\mathrm{a}}(1.08)$ & $40.58^{\mathrm{a}}(2.46)$ & $46.52^{\mathrm{a}}(3.75)$ \\
\hline 2 & $42.30^{\mathrm{a}}(6.75)$ & $5.65^{\mathrm{a}}(1.21)$ & $40.99^{\mathrm{a}}(2.32)$ & $47.31^{\mathrm{a}}(2.61)$ \\
\hline 3 & $45.11^{\mathrm{a} b \mathrm{~b}}(6.84)$ & $5.44^{\mathrm{a}}(1.40)$ & $44.45^{\mathrm{a}, \mathrm{b}}(2.42)$ & $45.77^{\mathrm{a}}(4.73)$ \\
\hline 4 & $47.40^{\mathrm{b}}(4.93)$ & $5.14^{\mathrm{a}}(1.12)$ & $46.81^{\mathrm{b}}(2.41)$ & $36.07^{\mathrm{b}}(3.93)$ \\
\hline 5 & $39.13^{\mathrm{c}}(6.23)$ & $4.67^{\mathrm{a}}(0.83)$ & $57.25^{\mathrm{c}}(2.68)$ & $37.61^{\mathrm{b}}(2.53)$ \\
\hline
\end{tabular}

AIM: Alcohol Insoluble Material

WSP: Water Soluble Polysaccharide

GuAc: Galacturonic acid

DM: Degree of Methylation

Data are presented as means with standard deviations of triplicate determinations. Mean values with different small letters in the same column for a given analysis are statistically significant $(p<0.05)$

Table 4: Characteristics of polysaccharides extracted from jujube cultivar P3 during ripening.

tins. The main goal was to achieve the flavor, aroma and consistency characteristics ascribed to the traditional jujube cake found in Africa. The optimized drying parameters were $45^{\circ} \mathrm{C} / 24 \mathrm{~h} /$ sliced fruits, and the cooking parameters were $13 \mathrm{~g}$ of jujube flour cooked for 10 mins with an intermediate grading of flour $(465 \mu \mathrm{m})$. After 7 mins of cooking, jujube flour was compacted, but the cake was better after $10 \mathrm{mins}$, when the specific jujube flavor was released. This property of compaction may be attributed to the gelling ability of pectin polysaccharides [31]. Indeed, our results showed a high WSP content during ripening $(6 \%)$, with a high content of galacturonic acid (50\%). Furthermore, with regard to its DM (less than 50\%), jujube polysaccharides were classified as "low methylated" polysaccharide. Therefore, the gel was created with bivalent ions such as calcium. Z. mauritiana Lamk cv Gola from Senegal revealed a high calcium content $(488 \mathrm{mg} / 100 \mathrm{~g} \mathrm{DW})$ [32]. Traditionally, the jujube cake was baked using the last ripening stage 5. However, the nutritional quality was very low in fresh fruit picked at this stage, as described in previous work. Fruits 3 exhibited a higher total phenolic content, ascorbic acid content and antioxidant capacities than Fruits 5 . Whereas the drying process decreased the ascorbic acid in Flour 3 and Flour 5, it did not affect the total phenolic content or antioxidant capacity. Surprisingly, cooking had a big impact on the flour, producing cakes with higher nutritional quality. Then, since Fruits 3 have a similar WSP content as Fruits 5 (Table 4), it will be interesting to bake the jujube cake with an earlier ripening stage which have more nutritional value. Furthermore, the change in rheological properties of polysaccharides during baking may involve the synergy of other phytochemicals [33], leading to an increase of the antioxidant activity. Moreover, it should be noted that pectins with high degree of esterification (49\%) from $Z$. jujuba have greater immunological activity [34]. For the increase of ascorbic acid in cake, it should be explained by the reduction of dehydroascorbate formed during the drying process, leading to ascorbate during cooking [35]. It should be noted that the high quality attributes of some jujube-based products such as beverages, compotes, jam, dried candy, syrup and cakes have been reported [36]. This enhanced nutritional quality has also been highlighted with conventional cakes enriched with $20 \%$ dried jujube. This study found an interesting nutritional advantage of processing the cake from a defined ripening stage of jujube fruits.

\section{Conclusion}

Overall, our results showed that reengineering traditional process leads to a jujube cake with high nutritional qualities and appreciated flavor. The elevated nutritional value of jujube from ripening stage
3 was found preserved and enhanced after the processing. Thus, the limited post-harvest life of jujube fruits may be overcome by processing including cake cookery. Further investigation would focus on the physiological relevance of the of the cake antioxidant capacity and may extend acceptability studies.

\section{Acknowledgement}

This publication is an output of AFTER (African Food Tradition revisited by Research) project, funded by European Union (FP7 $n^{\circ}$ 245-025) (AFTER, http:// www.after-fp7.eu). S.Z was supported by a grant provided by the Regional Board of Guadeloupe.

\section{References}

1. Pawlowska AM, Camangi F, Bader A, Braca A (2009) Flavonoids of Zizyphus jujuba L. and Zizyphus spina-christi (L.)Willd (Rhamnaceae) fruits. Food Chemistry 112: 858-862.

2. Li JW, Fan LP, Ding SD, Ding XL (2007) Nutritional composition of five cultivars of Chinese jujube. Food Chemistry 103: 454-460.

3. Zhang H, Jiang L, Ye S, Ye Y, Ren F (2010) Systematic evaluation of antioxidant capacities of the ethanolic extract of different tissues of jujube (Ziziphus jujuba Mill.) from China. Food and Chemical Toxicology 48: 1461-1465.

4. Zozio S, Servent A, Hubert O, Hiol A, Pallet D, et al. (2014b) Physicochemical and biochemical characterization of jujube (Ziziphus mauritiana Lamk) fruits ripening from two accessions grown in Guadeloupe. Scientia Horticulturae 175 290-297.

5. Shobha D, Bharati $P$ (2007) Value addtion to Ber (Zyziphus mauritiana Lamk.) through preparation of pickle. Kanataka J Agric Sci 20: 353-355.

6. Pareek S, Kitinoja L, Kaushik RA, Paliwal R (2009) Postharvest physiology and storage of ber. Stewart Postharvest Review.

7. Thanatcha R, Pranee A (2011) Extraction and characterization of mucilage in Ziziphus Mauritiana Lam. International Food Research Journal 18: 201-212.

8. Fraeye I, Duvetter T, Doungla, E, Van Loey A, Hendrickx M (2010) Finetuning the properties of pectin-calcium gels by control of pectin fine structure, gel composition and environmental conditions. Trends in Food Science \& Technology 21: 219-228.

9. Wang D, Zhao Y, Jiao Y, Yu L, Yang S, et al. (2012) Antioxidative and hepatoprotective effects of the polysaccharides from Zizyphus jujube cv. Shaanbeitanzao. Carbohydrate Polymers 88: 1453-1459.

10. Gonzaez CA, Alnaief M, Smirnova I (2011) Polysaccharide-based aerogelsPromising biodegradable carriers for drug delivery systems. Carbohydrate Polymers 86: $1425-1438$

11. Li JW, Ding SD, Ding XL (2007) Optimization of the ultrasonically assisted extraction of polysaccharides from Zizyphusjujuba cv. jinsixiaozao. Journal of Food Engineering 80: 176-183.

12. Li J, Shan L, Liu Y, Fan L, Ai L (2011) Screening of a functional polysaccharide from Zizyphus Jujuba cv. Jinsixiaozao and its property. Int J Biol Macromol 49: 255-259.

13. Dairou S, Biyanzi P, Pallet D, Ndjouenkeu R (2014) Traditional production processing and quality attributes of Ziziphus mauritiana in Savannah region of Cameroon. Journal of Scientific Research and Reports 3: 686-699.

14. Singleton VL, Orthofer R, Lamuela-Raventos RM (1999) Analysis of total phenols and other oxidation substrates and antioxidants by means of folinciocalteu reagent. Methods in Enzymology 299: 152-178.

15. Zozio S, Servent A, Cazal G, Mbeguie-A-Mbeguie D, Ravion S, et al. (2014a) Changes in antioxidant activity during the ripening of Jujube (Ziziphus Mauritiana Lamk). Food Chemistry 150: 448-456.

16. Li J, Fan L, Ding S (2011) Isolation, purification and structure of a new watersoluble polysaccharide from Zizyphus jujuba cv. Jinsixiaozao. Carbohydrate Polymers 83: 477-482.

17. Chang SC, Hsu BY, Chen BH (2010) Structural characterization of polysaccharides from Zizyphus jujuba and evaluation of antioxidant activity. International Journal of Biological Macromolecules 47: 445-453.

18. Huisman MMH, Oosterveld A, Schols HA (2004) Fast determination of 
Citation: Zozio S, Servent A, Hiol A, Mbeguie-A-Mbeguie D, Cosmidis L, et al. (2015) Processed Z. Mauritiana Lamk in the Formula of High Nutritional Value Cake. J Food Process Technol 6: 444. doi:10.4172/2157-7110.1000444

Page 6 of 6

the degree of methyl esterification of pectins by head-space GC. Food Hydrocolloids 18: 665-668.

19. Wafaa M, Abozied IMF, Helmy, Nadir A, Esmat, et al. (2011) Production and Development of New Products from Local and Chinese Ber Fruits. Australian Journal of Basic and Applied Sciences 5: 652-659.

20. Nicoli MC, Anese M, Parpinel M (1999) Influence of processing on the antioxidant properties of fruit and vegetables. Trends in Food Science and Technology 10: 94-100.

21. Turkmen N, Sari F, Velioglu YS (2005) The effect of cooking methods on total phenolics and antioxidant activity of selected green vegetables. Food Chemistry 93: 713-718.

22. Stewart AJ, Bozonnet S, Mullen W, Jenkins GI, Lean ME, et al. (2000) Occurrence of Flavonols in Tomatoes and Tomato-Based Products. J Agricult Food Chem 48: 2663-2669.

23. Xu G, Ye X, Chen J, Liu D (2007) Effect of Heat Treatment on the Phenolic Compounds and Antioxidant Capacity of Citrus Peel Extract. J Agricult Food Chem 55: 330-335.

24. Nwaichi EO (2013) Effect of heat treatment on the antioxidant properties of Tetrapleura tetraptera, Xylopia aethiopica and Piper guineense. International Journal of Biotechnology and Food Science 1: 1-5.

25. Yao Y, Ren G (2011) Effect of thermal treatment on phenolic composition and antioxidant activities of two celery cultivars. LWT-Food Science and Technology 44: 181-185.

26. Dini I, Tenore GC, Dini A (2013) Effect of industrial and domestic processing on antioxidant properties of pumpkin pulp. LWT-Food Science and Technology 53: $382-385$

27. Gao QH, Wu CS, Wang M, Xu BN, Du LJ (2012) Effect of Drying of Jujubes
(Ziziphusjujuba Mill.) on the Contents of Sugars, Organic Acids, $\alpha$-Tocopherol, $\beta$-Carotene, and Phenolic Compounds. J Agri Food Chem 60: 9642-9648.

28. Ravichandran K, Ahmed AR, Knorr D, Smetanska I (2012) The effect of different processing methods on phenolic acid content and antioxidant activity of red beet. Food Research International 48:16-20.

29. Kannan S, Thirumaran AS (2003) Physico-chemical changes during ripening of ber (Zizyphusmautiana Lam.) fruits on the plant and in storage. J Food Sci Technol 40: 550-551.

30. Wang H, Chen F, Yang H, Chen Y, Zhang L, et al. (2012) Effects of ripening stage and cultivar on physicochemical properties and pectin nanostructures of jujubes. Carbohydrate Polymers 89: 1180-1188

31. Evageliou V, Richardson RK, Morris ER (2000) Effect of pH, sugar type and thermal annealing on high-methoxy pectin gels. Carbohydrate Polymers 42 245-259.

32. Danthu P, Solovievc P, Tottec A, Tinee E, Ayessouf N, et al. (2002) Physicochemical characteristics and organoleptic compared wild jujube fruit and the Gola variety introduced in Senegal. Fruits 57: 173-182.

33. Nitta $Y$, Nishinari K (2005) Gelation and gel properties of polysaccharides gellan gum and tamarind xyloglucan. J Biol Macromol 5: 47-52.

34. Li J, Liu Y, Fan L, Ai L, Shan L (2011) Antioxidant activities of polysaccharides from the fruiting bodies of Zizyphus Jujuba cv. Jinsixiaozao. Carbohydrate Polymers 84: 390-394.

35. Barycki JJ, Asard H, Stone JM, Wilson MA, Banerjee R, et al. (2007) Antioxidant Molecules and Redox Cofactors. Redox Biochemistry, John Wiley and Sons Inc. New York, USA

36. Helmy IMF, Abozeid WM, Nadir A (2012) Nutritional Evaluation of Some Products from Ber Fruits. Nature and science 10: 37-46. 